\title{
Clinical Manifestation and Risk Factors of Tuberculosis Infection in Malaysia: Case Study of a Community Clinic
}

\author{
Rohan Shanmuganathan ${ }^{1} \&$ Indra Devi Shanmuganathan ${ }^{2}$ \\ ${ }^{1}$ Department of Internal Medicine, Hospital Sungei Buloh, Selangor, Malaysia \\ ${ }^{2}$ Graduate School of Management, Multimedia University, Cyberjaya, Malaysia \\ Correspondence: Indra Devi Subramaniam, Graduate School of Management, Multimedia University, Jalan \\ Multimedia, Cyberjaya 63100, Selangor, Malaysia. Tel: 03-83-125-716. E-mail: indra@mmu.edu.my
}

Received: November 18, 2014 Accepted: December 4, 2014 Online Published: December 31, 2014

doi:10.5539/gjhs.v7n4p110

URL: http://dx.doi.org/10.5539/gjhs.v7n4p110

\begin{abstract}
Introduction: The main aim of this study was to describe the clinical manifestation of tuberculosis infection cases in Malaysia and to determine the individual risk factors for their occurrence.

Methodology: The study adopted a quantitative research approach with use of descriptive statistical approach. The study setting was a community clinic which treats walk in patients who are mainly living and working in the surrounding areas. The study was conducted for a period of one year. All tuberculosis patients who sought treatment in the clinic during the time were included in this study. The total number of cases was 40. Data was collected from the medical records of the tuberculosis patients. The risk factors selected for investigation were demographic characteristics of age and sex, personal habits such as smoking, drug use and alcohol and presence of diseases such as human immunodeficiency virus positive $(\mathrm{HIV}+)$, diabetes mellitus, cancer, cyanotic heart disease, renal failure and steroid use.
\end{abstract}

Results: Patients in the age group ranging from 41 to 50 years had the highest incidence of the infection. Smoking appears to be the most important risk factor for contracting followed by drug abuse, HIV+ infection and diabetes mellitus.

Conclusions: People with diseases such as diabetes mellitus and HIV that are high risk factors for TB should be screened for TB so that early detection and intervention is possible. Educational programs should be carried out to create awareness among the at risk groups.

Keywords: Tuberculosis, clinical manifestation; risk factors, Malaysia

\section{Introduction}

\subsection{Incidence of Tuberculosis Cases}

Tuberculosis (TB) cases are on the rise more so in developing countries. According to Davies (2003) and Dye (2006), TB is foremost among diseases that cause mortality worldwide. The statistics indicate that 8.6 million people were infected with this disease in 2012 and the death due to the disease was about 8.6 million of which about a quarter were people who had been diagnosed positive for HIV. Many of these deaths could have been averted through treatment.

Among the cases worldwide, South East Asia tops the list with $29 \%$ followed by Africa (27\%), and Western Pacific regions (19\%). The two largest populated nations of the world also recorded high incidence of TB cases with India accounting for $26 \%$ and China registering $12 \%$. The incidence of TB cases is significantly lower in developed countries (WHO, 2013).

Coinfection of TB with HIV is on the rise. According to the Global TB Report 2013, among those who were infected with TB in 2012, HIV positive persons constituted about $13 \%$ off the total number. Further cause for worry is the emergence of multi-drug resistant TB cases worldwide estimated to be 450,000 for the same year with about 170,000 deaths being attributed to it.

Although the incidence of TB infection and death due to the disease is higher among men than women, it is among the top three causes of death for women. Of the 8.6 million new cases of TB globally in 2012, a third of them were women. Coinfection with HIV was responsible for the death of 160,000 of the 450,000 women who 
died of TB in 2012. Children under 15 years old represented $6 \%$ of TB cases worldwide and $8 \%$ of the mortality among HIV negative TB cases were children (WHO, 2013).

According to Frieden, Sterling, Munsiff, Watt and Dye (2006), TB can have detrimental effect on the economic situations of individuals and nations as most active cases of TB occur in persons between the ages of 19 and 49 . It is during this phase of their lives that people are actively involved in their career and contribute towards a nation's Gross Domestic Product (GDP).

\subsection{Cause of TB and Its Transmission}

TB is an infectious disease. It is caused by the bacteria Mycobacterium tuberculosis (Kumar, Abbas, Fausto, \& Mitchell, 2007). The Mycobacterium tuberculosis possesses a distinct cell wall which is necessary for the bacteria's survival because it contains a fatty acid called mycolic acid which provides a strong lipid barrier (Cantrell, Leavell, Marjanovic, Iavarone, Leary, \& Riley, 2013).

It is the physiological characteristics of this barrier that is responsible for problems in treating the disease because it provides the bacteria with resistance to antibiotics and the normal immunological mechanisms possessed by the host. The components of the cell wall both in terms of composition and quantity affect the bacteria's aggressiveness and escalation rate (Lee, Li, Chatterjee, \& Lee, 2005). The peptidoglycan polymer external to the bacterial cell membrane which gives the cell wall its rigidity adds to its impermeability. The survival of the mycobacteria within macrophages is facilitated by another cell wall constituent called lipoarabinomannan. This antigen is immunogenic and exists on the outside of the organism (Lee et al., 2005; Joe, Bai, Nacario, \&Lowary, 2007).

TB mostly attacks the lung. This type of infection is called pulmonary TB. TB can also infect organs other than the lung such as the lymphatics, pleura, bones/joints, or meninges. In the latter cases it is referred to as extrapulmonary TB. TB is spread by droplets released into the air by pulmonary or laryngeal TB patients when they cough or sneeze. These droplets are durable staying in the air several hours after their expulsion (Lee et al., 2005). According to the American Thoracic Society and Centers for Disease Control and Prevention (2000) many variables can influence the spread of the disease. Among these are the bacilli's number in the droplets, their aggressiveness, and the extent of their exposure to UV light and the availability of ventilation. Not all people who are infected with the bacteria go on to develop the disease. The probability of developing the disease is higher among persons exposed to risk factors. Therefore initiatives to control or prevent the disease would require addressing the risk factors.

\subsection{Pathophysiology}

When an individual inhales, the droplets containing the bacteria are dispersed throughout the person's airways but mainly on its upper part where mucus producing cells are present. Most of the bacilli are caught here. When this happens, the cilia present on the cells start pushing the mucus and the trapped bacilli upwards in an attempt to remove them from the body (Frieden, Sterling, Munsiff, Watt, \& Dye, 2003). This action is the first defence mechanism by the body to prevent infection by the bacteria (Jensen, Lambert, Iademarco, \& Ridzon, 2005).

Those that escape this system, end up in the alveoli. The alveoli macrophages are immune effectors cells that are present in large numbers in alveolar spaces (Korf, Pynaert, Tournoy Boonefaes, Van Oosterhout, Ginneberge, Haegeman et al., 2006.). The macrophages are the primary host cells for the Mybacterium tuberculosis. These macrophages are phagocytes and are part of the body's natural immune system whose function is to eliminate invading pathogens and prevent onset of diseases (Van Crevel, Ottenhoff, \& Van der Meer, 2002). The macrophages surround and engulf the mycobacteria in the droplets that end up in the alveoli (Frieden et al., 2003).

Lipoarabinomannan (LAM) is one of the key virulence factors for the bacteria. and plays a significant role in its phagocytosis (Li, Petrofsky, \& Bermudez, 2002). This compound in the cell wall of the mycobacteria interacts with the $\mathrm{C} 3$ proteins in the cell membrane of the host macrophage and enables recognition of the mycobacteria by the macrophage facilitating its engulfment by the latter. This results in phagocytosis of the mycobacteria.

A series of events result as a consequence of continuing phagocytosis of the mycobacteria by the macrophages. The infection could be controlled with the TB present in the host in a latent state or it could also lead to manifestation of the disease in its active form which is referred to as primary progressive TB (Frieden et al., 2003). The quality of the defenses possessed by the host and the strength of host defenses against the virulence of the mycobacteria will determine which of these two outcomes happen (Goyot-Revol, Innes, Hackforth, Hinks, \& Lalvani, 2006). 
Post ingestion by macrophages, the mycobacteria will continue to increase in numbers (Frieden et al., 2003) through cell divisions taking place at regular intervals (Porth, 2002). Mycobacteria infecting macrophages live in cytoplasmic vesicles that resist fusion with lysosomes and consequent destruction of the bacteria by macrophage bacteriocidal activity. Irrespective of the stage of development of the infection, the first initiative by the macrophages is to produce proteolytic enzymes and cytokines to try to weaken the mycobacteria. The cytokines attract $\mathrm{T}$ cells to the spot. The macrophages respond by presenting mycrobacterial antigens to the $\mathrm{T}$ cells. It is the start of the development of cell-mediated immunity van Crevel, Ottenhoff, Jos and van Meer, (2002).

Table 1. Differences in the stages of tuberculosis

\begin{tabular}{|c|c|c|c|}
\hline Early infection & $\begin{array}{l}\text { Early primary progressive } \\
\text { (active) }\end{array}$ & $\begin{array}{l}\text { Late primary progressive } \\
\text { (active) }\end{array}$ & Latent \\
\hline $\begin{array}{l}\text {-The host's immune system } \\
\text { combats the infection. } \\
\text {-Progression of the disease } \\
\text { takes place in the absence of } \\
\text { signs or symptoms. } \\
\text {-Patients could develop fever, } \\
\text { paratracheal } \\
\text { lymphadenopathy, } \\
\text { or dyspnea. } \\
\text {-The Infection may not } \\
\text { progress to active stage but } \\
\text { remain in a subclinical } \\
\text { condition. }\end{array}$ & $\begin{array}{l}\text {-The initial infection is not } \\
\text { controlled by the host's } \\
\text { Immune system } \\
\text {-The tissues become inflamed } \\
\text {-Patient exhibits nonspecific } \\
\text { signs or } \\
\text { symptoms for example fever, } \\
\text { loss of weight and fatigue. } \\
\text {-Cough that develops in this } \\
\text { stage is nonproductive. } \\
\text {-Result of chest radiograph is } \\
\text { normal and smear tests for } \\
\text { sputum is negative for } \\
\text { mycobacteria making } \\
\text { diagnosis difficult. }\end{array}$ & $\begin{array}{l}\text {-Cough in this stage is } \\
\text { productive. } \\
\text {-With the progress of the } \\
\text { disease, signs and symptoms } \\
\text { increase. } \\
\text {-Patient suffers more weight } \\
\text { loss, rales and anemia. } \\
\text {-Result of chest radiograph is } \\
\text { normal. } \\
\text {-Cultures of sputum are used } \\
\text { for diagnosis of the disease. }\end{array}$ & $\begin{array}{l}\text {-The Mycobacteria continues } \\
\text { to inhabit the host's body. } \\
\text {-Absence of signs or } \\
\text { symptoms. } \\
\text {-Patient does not feel sick. } \\
\text {-Patient is at risk of } \\
\text { reactivation of the disease. } \\
\text {-Chest radiograph shows } \\
\text { calcified granulomatous } \\
\text { lesions which have become } \\
\text { fibrotic. likelihood of } \\
\text {-There is } \\
\text { reappearance of the infection } \\
\text { when risk factors present in } \\
\text { the hosts cause } \\
\text { immunosuppression. }\end{array}$ \\
\hline
\end{tabular}

The progress of the disease depends essentially on the patient's immune system. The differences in stages of the TB as described by van Crevel, Ottenhoff, Jos and van Meer (2002) are presented in Table 1. These stages include latency, primary disease, primary progressive disease, and extrapulmonary disease. The manifestation of the disease is different in each stage.

\subsection{Background of the Problem}

There has been a steady increase in yearly notification of new cases of TB in Malaysia over the past 20 years. The absolute number of new cases has been increasing from about 15,000 new cases in 2002 up to 16,665 in 2006 (Ministry of Health, Malaysia, 2008). As of 2010, the TB case detection rate (\%, all forms) in Malaysia was 80.00 , its highest value over the past 20 years. TB case detection rate (all forms) is the percentage of newly notified TB cases (including relapses) to estimated incident cases (case detection, all forms) (WHO, 2010). TB is the second highest contagious disease in Malaysia with 22,710 cases in 2012. It is the highest cause of death among contagious diseases. In 2013 it claimed 1,597 lives as compared to 1,414 cases in 2012 (Subramaniam, 2014).

While it is important that appropriate and effective measures are used to treat those infected with TB, it is just as important to take actions to prevent the occurrence of the disease. One way of preventing the occurrence of the disease is to control its transmission from infectious TB cases. For an individual who has been infected with TB after exposure to infectious cases, the development of TB takes a two stage process. For those with strong immune system, the infection is contained. About $10-15 \%$ of those infected go on to develop active disease at some stage of their lives (Maher, 2009).

To prevent infection and manifestation of the disease, it is important understand the factors that contributes to both these states. The first step in control of TB is to understand the risk of infection after an individual has been exposed to infectious cases. According to Narasimhan, Wood, Raina, MacIntyre, and Mathai (2013) this is governed by a combination of factors that include the acuteness of the infectious source case, the physical 
closeness of the individual to the source case and the extent to which the individual possesses the social and behavioural risk factors such as smoking, alcohol, air pollution and overcrowded situations. In these conditions the transmission of the disease is high. Delay in diagnosis could also prolong the individual's exposure to the infectious patients and could therefore be another contributory factor.

The second step in control of the disease requires an understanding of the factors that accelerate the progression of infection to disease. All conditions that alter the immune response of the host increase the risk of progression to the disease. Among these are HIV, Diabetes, alcohol, malnutrition, tobacco smoke, and indoor air pollution. The prevalence of these factors vary from country to country accounting for the differential impact of these factors on the larger section of the population and progression from infection to TB disease. Therefore to prevent and control TB in Malaysia requires an understanding of the risk factors that are specific to the local context. This study aims to address this problem.

\section{Methodology}

\subsection{Research Design}

The study adopts a quantitative approach and a descriptive research design. The research framework is presented in Figure 1.

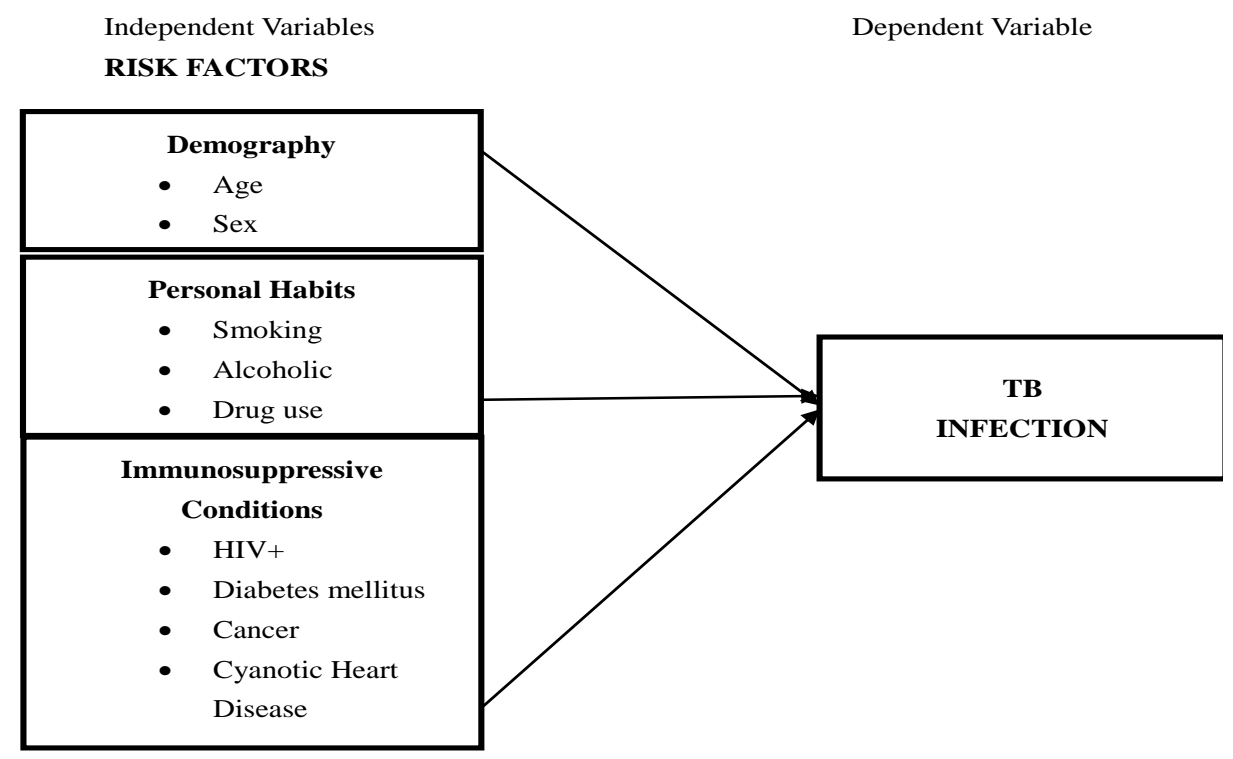

Figure 1. Research Framework

\subsection{Population and Sample}

The study setting is a community clinic which treats walk in patients who are mainly living and working in the surrounding areas. The study was conducted from 1 January 2012 to 31 December 2012. All TB patients who sought treatment in the clinic during the time were included in this study. It is therefore a census study. The total number of patients who fit this description was 40 . Since this study was carried out in one community clinic and comprised of outpatients, the findings are only generalizable to that clinic. However if the TB patients in this study are representative of microcosm of the TB patients in Malaysia, the finding of the study could be an indicator of the characteristics of TB patients in rest of Malaysia. Patients of the clinic are mainly those living and working in the surrounding areas.

\subsection{Data Collection}

The sources of data are the TB patients' medical records. The data was obtained retrospectively by reference to these cards. The medical records are in the form of cards and the information contained in them include demography of the patients (sex, age, nationality, race, marital status), personal habits (smoke, drink alcohol, take drugs), whether they suffer from other diseases (HIV/AIDS, diabetes mellitus, cancer, diseases of the liver), type of case, registration category and treatment outcomes. To ensure compliance with research ethics, the identity of the patients was not revealed and the data are analyzed collectively. 


\subsection{Data Analysis}

Descriptive statistics in the form of frequency and percentages was used to analyze the data and answer the research questions and objectives. Statistical tests in the form of chi square are required to determine whether there is significant association between risk factors and TB. However this test could not be conducted because the sample size was too small resulting in some cells being empty.

\section{Results}

\subsection{Demographic Profile of the Respondents}

The profile of the respondents in terms of demography is presented in Table 2.

Table 2. Demographic Profile of Respondents

\begin{tabular}{lll}
\hline Variables & Frequency & Percentage \\
\hline Sex & 31 & 77.5 \\
Male & 9 & 22.5 \\
Female & & \\
\hline Age Group (Years) & 8 & 20 \\
$20-30$ & 11 & 27.5 \\
$31-40$ & 12 & 30 \\
$41-50$ & 8 & 20 \\
$51-60$ & 2 & 2.5 \\
$>60$ & & \\
\hline Nationality & 32 & 80.0 \\
Malaysian & 7 & 20.0 \\
Non-Malaysia & & \\
\hline Race & 22 & 45 \\
Malays & 5 & 12.5 \\
Chinese & 5 & 12.5 \\
Indian & 7 & 17.5 \\
Indonesian & 1 & 2.5 \\
Cambodian & & \\
\hline Marital Status & 16 & 40 \\
Single & 24 & 60 \\
Married & 14 & 35 \\
\hline Occupation & 26 & 65 \\
Employed & & \\
Unemployed & & \\
\hline & & \\
\hline
\end{tabular}

There were more male patients $(77.5 \%)$ compared to female patients $(22.5 \%)$. The distribution of the patients by age is $20-30$ years $(20 \%), 31-40$ years $(27.5 \%), 41-50$ years $(30 \%), 51-60$ years $(20 \%)$ and those above 60 years constituted the remaining $2.5 \%$. Majority of the patients were Malaysian $(70 \%)$ with Malays forming the largest proportion (45\%). Chinese and Indians with $12.5 \%$ each made up the remaining $25 \%$. Indonesian was the majority (25\%) among the non-Malaysian. The remaining 2.5\% were Cambodians. With regards to marital status $60 \%$ were married while the remaining $40 \%$ were single. A large proportion (65\%) was unemployed.

\subsection{Category of Cases}

Table 3 describes the patients according to category of cases. Majority of them were new cases (87.5\%), 3 of them were treatment after interruption, there was 1 case each (2.5\%) for relapse and treatment failure. 
Table 3. Category of Cases

\begin{tabular}{lll}
\hline Category of cases & Frequency & Percentage \\
\hline New Case & 35 & 87.5 \\
Relapse & 1 & 2.5 \\
Treatment Failure & 1 & 2.5 \\
Treatment after Interruption & 3 & 7.5 \\
\hline
\end{tabular}

\subsection{Clinical Manifestation of the Disease}

Table 4 presents the clinical manifestation of the disease among the cases that were studied. Most of the cases were pulmonary TB (90\%) with only $10 \%$ being extra pulmonary TB.

Table 4. Clinical Manifestation of the Disease

\begin{tabular}{|c|c|c|}
\hline Variables & Frequency & Percentage \\
\hline \multicolumn{3}{|l|}{ Diagnosis } \\
\hline Pulmonary TB & 36 & 90 \\
\hline Extra Pulmonary TB & 4 & 10 \\
\hline \multicolumn{3}{|l|}{ Symptoms and Signs } \\
\hline Prolonged cough & 5 & 12.5 \\
\hline Prolonged cough + sputum & 4 & 10.0 \\
\hline Prolonged cough + bloody sputum & 1 & 2.5 \\
\hline Prolonged cough + bloody sputum + weight loss & 5 & 12.5 \\
\hline Prolonged cough + weight loss & 11 & 27.5 \\
\hline Sputum + weight loss but no cough & 3 & 7.5 \\
\hline \multicolumn{3}{|l|}{ Prolonged cough + bloody sputum + weight loss + fever + night sweat } \\
\hline Prolonged cough + bloody sputum + fever + no appetite & 2 & 5.0 \\
\hline Prolonged cough + sputum + weight loss + fever + sweat at night & 6 & 15.0 \\
\hline \multicolumn{3}{|l|}{ Prolonged cough + bloody sputum + weight loss + fever + no appetite } \\
\hline & 2 & 5.0 \\
\hline & 1 & 2.5 \\
\hline \multicolumn{3}{|c|}{$\begin{array}{l}\text { Results of investigation using sputum direct smear for acid fast bacilli } \\
(A F B)\end{array}$} \\
\hline Sputum with one smear positive & 20 & 50 \\
\hline Sputum with two smear positive & 4 & 10 \\
\hline Sputum with three sputum smear positive & 13 & 32.5 \\
\hline Sputum with smear negative & 3 & 7.5 \\
\hline
\end{tabular}

The TB patients displayed several different symptoms. These included prolonged cough (12.5\%), prolonged cough with sputum (10\%), prolonged cough with bloody sputum (2.5\%), prolonged cough with bloody sputum and weight loss $(12.5 \%)$, prolonged cough with weight loss $(27.5 \%)$, sputum with weight loss but no cough (7.5), prolonged cough with bloody sputum, weight loss, fever and night sweat (5\%), prolonged cough with bloody sputum, fever and no appetite $(15 \%)$, prolonged cough with sputum, weight loss, fever and sweat at night (5\%) and prolonged cough with bloody sputum, weight loss, fever and no appetite $(2.5 \%)$.

\subsection{Result of Sputum Direct Smear Test for Acid Fast Bacilli (AFB)}

Table 5 presents the result of testing for TB using the sputum direct smear for acid fast bacilli (AFB) found positive results for $92.5 \%$ of the cases while the remaining $7.5 \%$ tested negative. 
Table 5. Results of investigation using sputum direct smear for acid fast bacilli (AFB)

\begin{tabular}{lll}
\hline Results & Frequency & Percentage \\
\hline Sputum with one smear positive & 20 & 50 \\
Sputum with two smear positive & 4 & 10 \\
Sputum with three sputum smear positive & 13 & 32.5 \\
Sputum with smear negative & 3 & 7.5 \\
\hline
\end{tabular}

\subsection{Presence of Risk Factors}

The distribution of the patients according to whether they possess selected risk factors is presented in Table 6 .

Table 6. Distribution of cases by presence of risk factors

\begin{tabular}{|c|c|c|}
\hline Risk Factors & Frequency & Percentage \\
\hline \multicolumn{3}{|l|}{ Drugs User } \\
\hline Yes & 13 & 32.5 \\
\hline No & 27 & 67.5 \\
\hline \multicolumn{3}{|l|}{ Smoke } \\
\hline Yes & 19 & 47.5 \\
\hline No & 21 & 52.5 \\
\hline \multicolumn{3}{|l|}{ Drink Alcohol } \\
\hline Yes & 2 & 5 \\
\hline No & 38 & 95 \\
\hline \multicolumn{3}{|l|}{ HIV Positive } \\
\hline Yes & 5 & 12.5 \\
\hline No & 35 & 87.5 \\
\hline \multicolumn{3}{|c|}{ Diabetic mellitus } \\
\hline Yes & 5 & 12.5 \\
\hline No & 35 & 87.5 \\
\hline \multicolumn{3}{|l|}{ Cancer } \\
\hline Yes & 0 & 0 \\
\hline No & 40 & 100 \\
\hline \multicolumn{3}{|c|}{ Cyanotic Heart Disease } \\
\hline Yes & 1 & 2.5 \\
\hline No & 39 & 98.5 \\
\hline \multicolumn{3}{|l|}{ Renal failure } \\
\hline Yes & 1 & 2.5 \\
\hline No & 39 & 98.5 \\
\hline \multicolumn{3}{|c|}{ Steroid treatment } \\
\hline Yes & 1 & 2.5 \\
\hline No & 39 & 98.5 \\
\hline
\end{tabular}

Distribution by personal habits showed that a nearly a third of them (32.5\%) were drug users; nearly half of them smoked $(47.5 \%)$ and $(5 \%)$ drank alcohol. The results show $12.5 \%$ of the patients had HIV, $12.5 \%$ were diabetic, $2.5 \%$ each had cyanotic heart disease, renal failure and steroid treatment. None of the cases had cancer. Risk factors according to rank would be (1) smoking, (2) drug use, (3) HIV and diabetes mellitus (5) alcoholic (6) heart disease, renal failure and steroid use. Cancer does not appear to be a risk factor. 


\section{Discussion}

The main aim of this study was to determine whether there was association between selected risk factors and TB among Malaysians infected with the disease. The risk factors selected for investigation were demographic characteristics of age and sex, personal habits such as smoking, drug use and alcohol and presence of diseases such as HIV and diabetes mellitus, cancer, cyanotic heart disease, renal failure and steroid use. Other risk factors which have been identified in literature such as malnutrition, poverty, living in overcrowded dwellings and exposure to immigrants from countries with high incidence of TB could not be studied as these data were either incomplete or non-existent in the patients' medical cards.

Majority of the TB cases in this study were male. It does indicate that sex could be a risk factor for TB infection. This is similar to the research results of Neyrolles et al. (2009). However, the reason for fewer numbers of women could be due to lower number of notification. Women have been found to not to reveal their infection due to stigma attached to the disease. About a quarter of the cases were over the age of 50. However the age group with the highest percentage was between 41 and 50 years of age. Since there were no cases in the infant and very young age category, again it was difficult to make and conclusions about babies and young children being more susceptible to TB because their immunity would have developed fully as was stated by Marais et al. (2004). Smoking appears to be the most important risk factor for contracting TB among Malaysians. This is consistent with the research findings of Bates et al. (2007) and Lin et al. (2007). Impaired clearance of mucosal secretion and reduced phagocytic activities of the alveolar macrophages are some of the reasons for smokers being at high risk for TB infection. Drug use registered second highest frequency among the TB patients. Markowitz (1993), Friedman et al. (1996) and Kaizer et al. (2000) all had similar results. Impaired immune system both natural and cell mediated have been cited as some of the reasons for drug use being a risk factor especial in latent cases. One in eight of the TB patients were HIV suggesting that the latter infection could be a risk factor. Corbett et al. (2003) found HIV infection in patients reduced their immunity making them highly susceptible to TB infection. Similar results were found by Lawn et al. (2006) and De Riemer et al. (2007). Diabetes mellitus also appears to be a risk factor for TB infection among Malaysians. This finding is consistent with that of Alisjahbana et al. (2007) and Baker et al. (2007). The presence of diabetes impairs the natural and adaptive immune responses to TB. There was 1 case each for renal failure, heart disease and steroid use and none for cancer. The little or no presence of this disease among the TB cases that was studied could be due to chance.

\section{Conclusion}

People with diseases such as diabetes mellitus and HIV that are high risk factors for TB should be screened for TB so that early detection and intervention is possible. Educational programmes should be carried out to create awareness in people regarding the dangers of smoking; alcoholism and drug use especially their susceptibility to TB. There should be aggressive vaccination campaign specifically for the very old and the very young and among men so that their vulnerability to TB is reduced.

It is noted that this study has several limitations. Since data was collected from the TB patients' medical records, only information collected in the cards could be used as variables in the study. This means that other risk factors such as malnutrition (indicated by body mass), living conditions, their social environment, age variations were not available to be used as variables in the study. The study was conducted in one community clinic with walk-in TB patients; as a result it is not generalizable to a larger population. In order to address these short comings, further research should be carried out with a larger population and covering bigger geographical area. A research instrument specifically designed for the research consisting of both structured and unstructured questions should be used to collect data.

\section{References}

Alisjahbana, B., Sahiratmadja, E., Nelwan, E. J., Purwa, A. M., Ahmad, Y., Ottenhoff, T. H., ... van Crevel, R. (2007). The effect of type 2 diabetes mellitus on the presentation and treatment response of pulmonary tuberculosis. Clin Infect Dis., (4), 428-435. http://dx.doi.org/10.1086/519841

Alisjahbana, B., van Crevel, R., Sahiratmadja, E., den Heijer, M., Maya, A., Istriana, E., ... van der Meer, J. W. (2007). Diabetes mellitus is strongly associated with tuberculosis in Indonesia. Int J Tuberc Lung Dis. 10(6), 696-700.

American Thoracic Society and Centers for Disease Control and Prevention. (2000). Diagnostic standards and classification of tuberculosis in adults and children. Am J Respir Crit Care Med., 161(4 pt 1), 1376-1395.

Arcavi, L., \& Benowitz, N. L. (2004). Cigarette smoking and infection. Arch Intern Med., 164(20), 2206-2016. 
http://dx.doi.org/10.1001/archinte.164.20.2206

Baker, M. A., Harries, A. D., Jeon, C. Y., Hart, J. E., Kapur, A., Lönnroth, K., ... Murray, M. B. (2007). The impact of diabetes on tuberculosis treatment outcomes: a systematic review. BMC Med., 2, 81.

Bates, M. N., Khalakdina, A., Pai, M., Chang, L., Lessa, F., \& Smith, K. R. (2007). Risk of tuberculosis from exposure to tobacco smoke: a systematic review and meta-analysis. Arch Intern Med., 167(4), $335-342$. http://dx.doi.org/10.1001/archinte.167.4.335

Bouman, A., Heineman, M. J., \& Faas, M. M. (2005). Sex hormones and the immune response in humans. Hum Reprod Update, 11(4), 411-423. http://dx.doi.org/10.1093/humupd/dmi008

Bucher, H. C., Griffith, L. E., Guyatt, G. H., et al. (1999). Isoniazid prophy-laxis for tuberculosis in HIV infection: a meta-analysis of ran-domized controlled trials. AIDS, 13, 501-507. http://dx.doi.org/10.1097/00002030-199903110-00009

Cantrell, S. A., Leavell, M. D., Marjanovic, O. I., Anthony, T. L., Julie, A., \& Riley, L. W. (2013). Free mycolic acid accumulation in the cell wall of the mce1 operon mutant strain of Mycobacterium tuberculosis. Journal of Microbiology, 51, 619-626. http://dx.doi.org/10.1007/s12275-013-3092-y

Converse, P. J., Jones, S. L., Astemborski, J., Vlahov, D., \& Graham, N. M .(1997). Comparison of a tuberculin interferon-gamma assay with the tuberculin skin test in high-risk adults: effect of human immunodeficiency virus infection. J Infect Dis., 176, 144-150. http://dx.doi.org/10.1086/514016

Corbett, E. L., Watt, C. J., Walker, N., Maher, D., Williams, B. G., Raviglione, M. C., \& Dye, C. (2003). The growing burden of tuberculosis: global trends and interactions with the HIV epidemic. Arch Intern Med., 163(9), 1009-1021. http://dx.doi.org/10.1001/archinte.163.9.1009

Daley, C. D., Small, P. M., Schecter, G. S., Schoolnik, G. K., McAdam, R., Jacobs, R., \& Hopewell. (1992). An outbreak of tuberculosis with accelerated progression among persons infected with the human immunodeficiency virus: An analysis using restriction-fragment-length polymorphisms. N Engl J Med., 326, 231-235. http://dx.doi.org/10.1056/NEJM199201233260404

Davies, P. D. (2003). The world-wide increase in tuberculosis: how demographic changes, HIV infection and increasing numbers in poverty are increasing tuberculosis. Ann Med., 35(4), $235-243$. http://dx.doi.org/10.1080/07853890310005713

Delamaire, M., Maugendre, D., Moreno, M., Le Goff, M. C., Allannic, H., \& Genetet, B. (1997). Impaired leucocyte functions in diabetic patients. Diabet Med. 14(1), $29-34$. http://dx.doi.org/10.1002/(SICI)1096-9136(199701)14:1<29::AID-DIA300>3.0.CO;2-V

DeRiemer, K., Kawamura, L. M., Hopewell, P. C., \& Daley, C. L. (2007). Quantitative impact of human immunodeficiency virus infection on tuberculosis dynamics. Am J Respir Crit Care Med., 176(9), 936-944. http://dx.doi.org/10.1164/rccm.200603-440OC

Dye, C. (2006). Global epidemiology of tuberculosis Lancet. 367(9514), $938-940$. http://dx.doi.org/10.1016/S0140-6736(06)68384-0

Falagas, M. E., Karageorgopoulos, D. E., \& Tansarli, G. S. (2013). Continuous versus Conventional Infusion of Amphotericin B Deoxycholate: A Meta-Analysis. PLoS One. 8(10), e77075. http://dx.doi.org/10.1371/journal.pone.0077075

Ferrara, G., Murray, M., Winthrop, K., Centis, R., Sotgiu, G., Migliori, G. B., Maeurer, M., \& Zumla, A. (2012). Risk factors associated with pulmonary tuberculosis: smoking, diabetes and anti-TNF $\alpha$ drugs. Curr Opin Pulm Med, 18(3) 233-240. http://dx.doi.org/10.1097/MCP.0b013e328351f9d6

Fok, A., Numata, Y., Schulzer, M., \& FitzGerald, M. J. (2008). Risk factors for clustering of tuberculosis cases: a systematic review of population-based molecular epidemiology studies. Int J Tuberc Lung Dis. 12(5), 480-92.

Frieden, T. R., Sterling, T. R., Munsiff, S. S., Watt, C. J., \& Dye, C. (2003). Tuberculosis. Lancet, 362,887 -899. http://dx.doi.org/10.1016/S0140-6736(03)14333-4

Friedman H, Newton C, Klein TW. (2003). Microbial infections, immunomodulation, and drugs of abuse. Clin Microbiol Rev., 16, 209. http://dx.doi.org/10.1128/CMR.16.2.209-219.2003

Friedman, L. N., Williams, M. T., Singh, T. P., \& Frieden, T. R. (1996). Tuberculosis, AIDS, and death among substance abusers on welfare in New York City. $N$ Engl J Med., 334, 828-833. 
http://dx.doi.org/10.1056/NEJM199603283341304

Guyot-Revol, V., Innes, J. A., Hackforth, S., Hinks, T., \& Lalvani, A. (2006). Regulatory T cells are expanded in blood and disease sites in patients with tuberculosis. American Journal of Respiratory and Critical Care Medicine, 173(7), 803-810. http://dx.doi.org/10.1164/rccm.200508-1294OC

Houtmeyers, E., Gosselink, R., Gayan-Ramirez, G., \& Decramer, M. (1999). Regulation of mucociliary clearance in health and disease. Eur Respir J., 13, 1177+1188. http://dx.doi.org/10.1034/j.1399-3003.1999.13e39.x

Jensen, P. A., Lambert, L. A., Iademarco, M. F., \& Ridzon, R. F. (2005). Guidelines for preventing the transmission of Mycobacterium tuberculosis in Health Care Setting. MMWR, 54(17), 1-144.

Jeon, C. Y., \& Murray, M. B. (2008). Diabetes mellitus increases the risk of active tuberculosis: a systematic review of 13 observational studies. PLoS Med., 2(7), 1091-1101.

Joe, M., Bai, Y., Nacario, R. C., \& Lowary, T. L. (2007). Synthesis of the docosanasaccharide arabinan domain of mycobacterial arabinogalactan and a proposed octadecasaccharide biosyn-thetic precursor. J Am Chem Soc, 129(32), 9885-9901. http://dx.doi.org/10.1021/ja072892+

Keizer, S. T., Langendam, M. M., van Deutekom, H., Coutinho, R. A., \& van Ameijden, E. J. (2000). How does tuberculosis relate to HIV positive and HIV negative drug users? J Epidemiol Commun H. 54, 64-68. http://dx.doi.org/10.1136/jech.54.1.64

Korf, J. E., Pynaert, G., Tournoy, K., Boonefaes, T., Van Oosterhout, A., Ginneberge, D., Haegeman, A. et al. (2006). Macrophage reprogramming by mycolic acid promotes a tolerogenic response in experimental asthma. Am. J. Respir. Crit. Care Med., 174, 152-160. http://dx.doi.org/10.1164/rccm.200507-1175OC

Kumar, V., Abbas, A. K., Fausto, N., \& Mitchell, R. N. (2007). Robbins Basic Pathology (8th ed.). Saunders Elsevier.

Lawn, S. D., Bekker, L. G., Middelkoop, K., Myer, L., \& Wood, R. (2006). Impact of HIV infection on the epidemiology of tuberculosis in a peri-urban community in South Africa: the need for age-specific interventions. Clin Infect Dis, 42(7), 1040-1047. http://dx.doi.org/10.1086/501018

Lee, R. E. B., Li, W., Chatterjee, D., \& Lee, R. E. (2005). Rapid structural characterization of the arabinogalactan and lipoarabinomannan in live mycobacterial cells using 2D and 3D HR-MAS NMR: structural changes in the arabinan due to ethambutol treatment and gene mutation are observed. Glycobiology, (2), 139-151.

Li, Y. J., Petrofsky, M., \& Bermudez, L. E. (2002). Mycobacterium tuberculosis uptake by recipient host macrophages is influenced by environmental conditions in the granuloma of the infectious individual and is associated with impaired production of interleukin-12 and tumor necrosis factor alpha. Infect. Immun., 70(11), 6223-6230. http://dx.doi.org/10.1128/IAI.70.11.6223-6230.2002

Lifson, A. R., Grant, S. M., Lorvick, J., et al. (1997). Two-step tuberculin skin testing of injection drug users recruited from community-based settings. Int J Tuberc Lung D., 1, 128-134.

Lin HH, Ezzati M, Murray M. (2007). Tobacco smoke, indoor air pollution and tuberculosis: a systematic review and meta-analysis. PLoS Med. 4(1):e20. http://dx.doi.org/10.1371/journal.pmed.0040020

Lönnroth, K., Williams, B. G., Stadlin, S., Jaramillo, E., \& Dye, C. (2008). Alcohol use as a risk factor for tuberculosis - a systematic review. BMC Public Health, 8, 289. http://dx.doi.org/10.1186/1471-2458-8-289

Maher, D. (2009).The natural history of Mycobacterium tuberculosis infection in adults in Tuberculosis: A Comprehensive Clinical Reference. In HS Schaaf and A Zumla Eds., Elsevier Health Sciences, pp. $129-132$.

Marais, B. J., Gie, R. P., Schaaf, H. S., Hesseling, A. C., Obihara, C. C., Starke, J. J., Enarson, D. A., ... Beyers, N. (2004). The natural history of childhood intra-thoracic tuberculosis: a critical review of literature from the pre-chemotherapy era. Int J Tuberc Lung Dis., 8(4), 392-402

Markowitz, N., Hansen, N. I., Wilcosky, T. C., Hopewell, P. C., et al. (1993). Tuberculin and Anergy Testing in HIV-Seropositive and HIV-Seronegative Persons. Ann Int Med., 119, $185-93$. http://dx.doi.org/10.7326/0003-4819-119-3-199308010-00002

Marriot, T., \& Huet-Hudson, Y. M. (2006). Sexual dimorphism in innate immune responses to infectious organism. Immunol. Res., 34, 177-192. http://dx.doi.org/10.1385/IR:34:3:177

Maurya, V., Vijayan, V. K., \& Shah, A. (2002). Smoking and tuberculosis: an association overlooked. Int J 
Tuberc Lung Dis., 6(11), 942-51.

Ministry of Health Malaysia. (2008). National Tuberculosis Control Programme, Disease Control Division.

Narasimhan, P., Wood, J., Macintyre, C. R., \& Mathai, D. (2013). Risk factors for tuberculosis. Pulmonary Medicine, 2013, 1-11. http://dx.doi.org/10.1155/2013/828939

Neyrolles, O., \& Quintana-Murci, L. (2009). Sexual Inequality in Tuberculosis. PLoS Med., 6(12), e1000199. http://dx.doi.org/10.1371/journal.pmed.1000199

Porth, C. M. (2002). Alterations in respiratory function: respiratory tract infections, neoplasms, and childhood disorders. In: Porth, C. M, \& Kunert, M. P. Pathophysiology: Concepts of Altered Health States. Philadelphia, PA: Lippincott Williams \& Wilkins pp.615-61.

Reinout van Crevel, Tom, H. M., Ottenhoff, Jos, W. M., \& van der, M. (2002). Innate immunity of Mycobacterium tuberculosis. Clin Microbiol Rev., $294-309$. http://dx.doi.org/10.1128/CMR.15.2.294-309.2002

Reyes, J. C., Robles, R. R., Colon, H. M., Marrero, C. A., Castillo, X., \& Melendez, M. (1996). Mycobacterium tuberculosis infection among crack and injection drug users in San Juan, Puerto Rico. P R Health Sci J., 15, 233-226

Shafer, R. W., Singh, S. P., Larkin, C., \& Small, P. M. (1995). Exogenous reinfection with multidrug-resistant Mycobacterium tuberculosis in an immunocompetent patient. Tuber Lung Dis., 76(6), 575-577. http://dx.doi.org/10.1016/0962-8479(95)90537-5

Slama, K., Chiang, C. Y., Enarson, D. A., Hassmiller, K., Fanning, A., Gupta, P., \& Ray, C. (2007). Tobacco and tuberculosis: a qualitative systematic review and meta-analysis. Int J Tuberc Lung Dis., 11(10), 1049-1061.

Smith, R., Cattamanchi, A., Steingart, K. R., Denkinger, C., Dheda, K., Winthrop, K. L., \& Pai, M. (2011). Interferon- $\gamma$ release assays for diagnosis of latent tuberculosis infection: evidence in immune-mediated inflammatory disorders. Curr Opin Rheumatol, (4), 377. http://dx.doi.org/10.1097/BOR.0b013e3283474d62

Stalenhoef, E., Alisjahbana, B., Nelwan, E. J. et al. (2008). The role of interferon-gamma in the increased tuberculosis risk in type 2 diabetes mellitus. European Journal of Clinical Microbiology and Infectious Diseases, 27(2), 97-103. http://dx.doi.org/10.1007/s10096-007-0395-0

Subramaniam, S. (2014). Improving performance towards detection, treatment and caring of TB patients. Speech presented at the World TB Day 2014. The Sun, 1 April.

Supori, M. (2002). Effects of cigarette smoke on the immune system. Nature Reviews Immunology, 2, $372-377$. http://dx.doi.org/10.1038/nri803

Szabo, G. (1997). Alcohol's contribution to compromised immunity. Alcohol Health \& Research World, 21(1), 31-38.

Van Crevel, R., Ottenhoff, T. H., \& van der Meer, J. W. (2002). Innate immunity to Mycobacterium tuberculosis. Clin Microbiol Rev. 15(2):294-309. http://dx.doi.org/10.1128/CMR.15.2.294-309.2002

Wei, G., Moss, J., \& Yuan, C. S. (2003). Opioid-induced immunosuppression: is it centrally mediated or peripherally mediated? Biochem $\quad$ Pharmacol., $\quad 65,1761-1766$. http://dx.doi.org/10.1016/S0006-2952(03)00085-6

Winthrop, K. L., Varley, C. D., Ory, J., Cassidy, P. M, \& Hedberg, K. (2011). Pulmonary Disease Associated with Nontuberculous Mycobacteria, Oregon, USA. Emerg Infect., 17(9), 1760-1761. http://dx.doi.org/10.3201/eid1709.101929

World Health Organisation. (2013). The Global Tuberculosis Report 2013. WHO Press, World Health Organization.

Yanbaeva, D. G., Dentener, M. A., Creutzberg, E. C., Wesseling, G., \& Wouters, E. F. (2007). Systemic effects of smoking. Chest. 131(5), 1557-1566. http://dx.doi.org/10.1378/chest.06-2179

\section{Copyrights}

Copyright for this article is retained by the author(s), with first publication rights granted to the journal.

This is an open-access article distributed under the terms and conditions of the Creative Commons Attribution license (http://creativecommons.org/licenses/by/3.0/). 